\title{
The Impact of Corporate Strategy on Enterprise Innovation Based on the Mediating Effect of Corporate Risk-Taking
}

\author{
Rui Li ${ }^{1, *}$, Yongmei Cui ${ }^{1}$ and Yajun Zheng ${ }^{1,2}$ \\ 1 School of Economics and Management, Beijing Jiaotong University, Beijng 100044, China; \\ ymcui@bjtu.edu.cn (Y.C.); ibtzoya@hotmail.com (Y.Z.) \\ 2 School of Economics and Management, East China Jiaotong University, Nanchang 330013, China \\ * Correspondence: lirui19900121@bjtu.edu.cn
}

check for updates

Citation: Li, R.; Cui, Y.; Zheng, Y. The Impact of Corporate Strategy on Enterprise Innovation Based on the Mediating Effect of Corporate Risk-Taking. Sustainability 2021, 13, 1023. https://doi.org/ $10.3390 /$ su13031023

Academic Editor: Samuel Adomako, Albert Danso

Received: 23 December 2020

Accepted: 19 January 2021

Published: 20 January 2021

Publisher's Note: MDPI stays neutral with regard to jurisdictional claims in published maps and institutional affiliations.

Copyright: (c) 2021 by the authors. Licensee MDPI, Basel, Switzerland. This article is an open access article distributed under the terms and conditions of the Creative Commons Attribution (CC BY) license (https:// creativecommons.org/licenses/by/ $4.0 /)$.

\begin{abstract}
Corporate strategy and enterprise innovation are highly relevant to corporate sustainability. Although previous studies on corporate strategy and enterprise innovation have yielded many results, a consensus regarding the relationship between the two is still lacking. The purpose of this study was to empirically analyze the impact of corporate strategy on corporate innovation performance and analyze corporate risk-taking as a potential factor mediating such. Based on data for listed Chinese A-share manufacturing companies for 2008 to 2018, this empirical study found that corporate strategy and corporate innovation show an inverted U-shaped relationship. Corporate risktaking plays a mediating effect between corporate strategy and corporate innovation performance. This study expands the knowledge on situational variables and the mechanism by which corporate strategy might impact enterprise innovation and can enlighten managers to promote the sustainable development of manufacturing enterprises.
\end{abstract}

Keywords: corporate risk-taking; enterprise innovation; corporate strategy; mediating effect

\section{Introduction}

As rising concerns about environmental and social issues and increasing stakeholder and regulatory demands force companies to adapt, the latter are under ever greater pressure to lower their impact on the environment and raise their contribution to society by pursuing corporate sustainability and drawing up suitable strategies for this [1]. A growing number of studies suggest that enterprise innovation is the main driving force for corporate sustainability. If companies want to survive, develop and remain invincible, they have to adapt to the new environment and achieve sustainable development through enterprise innovation [2,3]. The sudden outbreak of COVID-19 in 2020 has had a major impact on all industries. Facing the current, increasingly complex international environment and highly dynamic competitive environment, companies need to continue to enhance its their strategic adaptability, make strategic adjustments and transformations in a timely manner, and improve their own risk-taking levels to enhance their innovative capabilities and efficiency, so as to achieve corporate sustainability in a fiercely competitive environment.

Strategic management theory states that the behavioral decisions and management activities of enterprises are usually guided by their strategies. Corporate strategy determines the developmental directions of enterprises and access to external knowledge, and affects the methods, behavior and performance of a company's innovation [4]. In order to cope with the changeable external environment and ensure sustainable development, enterprises need to make corresponding strategic choices [5]. With both corporate strategy and enterprise innovation being the centerpiece of enterprise competitiveness, the influence of corporate strategy on innovation has always been a hot issue among policy makers, academia and the public. Different corporate strategies may have different effects on innovation performance [6]. A differentiation strategy emphasizes differences from competitors in the products or services offered. Enterprises tend to increase innovation 
input and product innovation activities to improve their own innovation abilities [7]. The low-cost strategy gives priority to the realization of scale benefits by controlling costs and increasing the sales volume. Enterprises can thereby minimize innovation investments that have long return periods and high risk, and the low-cost strategy is not highly dependent on enterprise innovation [8].

Although previous studies have produced a series of fruitful results [6,9], consensus has not yet been reached regarding the relationship between corporate strategy and enterprise innovation. We believe that the main reasons for this are as follows: (1) The influence of corporate strategy on enterprise innovation is not based on a single mechanism; there are a variety of channels, and different mechanisms produce different results. (2) In different situations, the effects of various relevant mechanisms are different, and the relationship between corporate strategy and enterprise innovation differs accordingly. (3) Differences in the methods of sample selection and variable measurement have led to inconsistent findings.

This study chooses corporate risk-taking as a channel for studying the mechanism by which corporate strategy influences enterprise innovation, because enterprise innovation activities have high-risk characteristics, and such high risk can discourage an enterprise from innovating. Therefore, corporate innovation willingness directly affects innovation performance, and the former is reflected in corporate risk-taking. To some extent, the risk-taking level of an enterprise reflects the enterprise's risk preference [10], the ability and willingness of enterprises to take risks are important for companies to be able to improve their innovation ability and achieve innovation performance [11,12], inevitably affecting innovation performance following different strategic choices made by the organization. However, there is still a lack of in-depth discussion on how the relationship between corporate strategy and corporate innovation is affected by corporate risk-taking [13], and the specific mechanism has not been elucidated. Based on the above analysis, this article intends to discuss the following issues: How does corporate strategy affect corporate innovation? Does corporate strategy affect innovation performance through corporate risktaking? In order to explore the above issues, considering the mediating factor of corporate risk-taking, this study used data for listed Chinese A-share manufacturing companies for 2008 to 2018, and empirically examined the influence of corporate strategy on enterprise innovation and the mechanisms. This paper reveals and supplements the influence of corporate strategy on enterprise innovation and the conduction path, and then provides manufacturing companies with management enlightenment for the innovation investment decision-making.

This paper makes three contributions. First, while previous researches on enterprise innovation have mostly focused on the impact of corporate governance, manager characteristics, organizational capital structure, and the external institutional environment on corporate innovation [14,15], this research focused on corporate strategy, which is one of the key organizational-level factors affecting corporate innovation investment; explored the impact of corporate strategic positioning on enterprise innovation through the financial data of listed companies; provided firm-level empirical evidence to explain the relationship between corporate strategy and corporate innovation; and further expanded the research literature on the factors influencing enterprise innovation. Second, the influence of corporate strategy on enterprise innovation is affected by many factors. However, in-depth analysis of the mechanisms by which organizational strategic factors affecting enterprise innovation performance is scarce $[13,16]$. The research shows that corporate risk-taking levels obviously affect the strategic investment decisions in the process of enterprise innovation, and companies that adopt different strategies have different innovation performance [17,18]. This research empirically verifies that corporate risk-taking partially mediates the influence of corporate strategy on enterprise innovation. This paper not only expands the known situational variables and mediators between corporate strategy and enterprise innovation but also further enriches the research on the consequences of corporate strategy for financial investment. Third, the conclusions of this research can provide enlightenment 
for the managers of Chinese manufacturing enterprises, helping them to make innovative strategic decisions. Since corporate strategy has an important influence on corporate financial investment, clarifying the impact of the former on enterprise innovation and its mechanism will help enterprises to make reasonable investment decisions based on their own strategic characteristics.

\section{Theoretical Background and Hypotheses}

Corporate strategy determines the future developmental direction and resource allocation mode of an enterprise, which has always been a hot and key issue in enterprise strategic management. Scholars classify the types of corporate strategy from different perspectives. For example, Miles and Snow [17] proposed three types of corporate strategy: defender, prospector and analyzer. These types represent unique and consistent repetitive behavior in analyzing the environment, the breadth of product/market areas, innovation and the use of technology to solve problems [4]. Porter [19] believed that companies can achieve excellent performance by establishing cost leadership, product differentiation and focused strategies that distinguish them from competitors' products and services. It is worth noting that Bentley et al. [18] constructed a discrete variable for corporate strategy from six aspects based on the strategic framework of Miles and Snow [17]. It was the first time that corporate financial data were used to measure the types of corporate strategies, which greatly promoted research on corporate strategy and corporate financial behavior. Existing studies on the economic consequences of corporate strategies mainly focus on the impact of strategic differences on corporate value $[4,6]$, the quality of financial information [18], investment decisions [20], the risks of stock price crashes [21], corporate financial behavior [22-24] and corporate governance [25]. Habib and Hasan [21] empirically examined the effect of firm-level business strategies on the risks of future stock price crashes and the extent to which equity overvaluation moderates this relationship. It was found that firms adopting innovative business strategies (prospectors) are more prone to future crash risk than defenders. It was also found that prospectors are more prone to equity overvaluation, which, in turn, increases future crash risk. Wang and Duan [24] investigated the impact of corporate strategy on management earnings forecasts based on data for listed Chinese A-share listed firms for 2006 to 2015. It was found that corporate strategy has a significant impact on management earnings forecasts; firms with offensive strategies are more likely to voluntarily disclose management earnings forecasts but create less precise and less accurate forecasts than defender firms.

\subsection{Corporate Strategy and Enterprise Innovation}

Innovation can be defined as the process in which an organization implements new or significantly improved products (goods or services), processes, new marketing methods or organizational methods. Innovations can be either product- or process-based [26]. Process innovation may be necessary for the successful implementation of new products, but enterprises tend to pay more attention to product innovation [12]. Although enterprise innovation has the characteristics of high investment and high risk, it is one of the main drivers of organizational growth and sustainability.

In the context of the current deepening of the global innovation value chain, fierce competition in the global market and the widespread application of emerging technologies such as artificial intelligence, big data and cloud computing are profoundly changing innovation methods, innovation iteration cycles and organizational innovation boundaries. In order to cope with the uncertainty of the environment, corporate managers must continuously improve their strategic matching and adaptability and adjust their corporate resource allocation, organizational structure, product strategy, market channels, customer positioning, service management, etc., in a timely fashion, so as to improve financial performance. Strategic positioning not only determines the developmental directions and resource allocation modes of enterprises but also determines investment decisions, risk-aversion strategies, information asymmetry, methods of knowledge acquisition and corporate gov- 
ernance, thereby affecting corporate innovation performance and financial performance [6]. Research shows that corporate strategy not only has an important impact on corporate competitiveness and performance [27] but also drives companies to pursue product innovation, market development, technological innovation and management innovation [28]. A company's strategic flexibility affects investment behavior. A reasonable range of strategic changes can not only help enterprises to adapt to the environment and cope with political risks but also help companies to reduce product costs, improve product quality and provide new products in a timely manner; control the competitive landscape and realize competitive advantages in innovation; and ultimately achieve excellent performance in an uncertain and fiercely competitive economic environment [9,29].

The radicalness of corporate strategy affects innovation performance, and different corporate strategies can produce different innovation performance. Smith and Tushman [28] believed that utilization strategy and development strategy are two inseparable types of corporate strategy that have important implications for innovation performance. Studies have shown that prospector and defender strategies expose firms to different required levels of investment, monitoring and managerial discretion, which have important implications for managerial investment decisions and corporate innovation [20,21]. At present, no agreement has been achieved on how corporate strategy affects corporate innovation. Some scholars believe that there is a linear positive or negative correlation between corporate strategy and innovation performance. Cingöz and Akdoğan [9] selected a sample of Turkish companies to empirically study the relationship between strategic flexibility, environmental vitality and innovation performance, and the results verified a positive relationship between strategic flexibility and corporate innovation performance. However, some studies have found that the relationship between company strategy and innovation performance is not a simple and linear. Miles and Snow [17] divided corporate strategy into three types according to the degree of strategic aggressiveness, from low to high—offensive strategy, analytical strategy and defensive strategy—which would have different influences on corporate innovation activities. In general, companies with an offensive strategy are experiencing rapid growth and violent fluctuation, hence facing a higher risk, and a product differentiation strategy is likely to be its prominent. In order to obtain a competitive advantage, enterprises tend to increase innovation investment, pursue new products and expand into new fields, in order to improve their innovation ability and performance. Companies with defensive strategies generally have relatively stable business, and costleading strategies may be prominent. Companies are cautious about increasing investment in innovation, tending to maintain the existing product market and pay more attention to product services and efficiency to maintain steady growth in corporate performance. Based on the above analysis, this paper proposes the following hypothesis:

Hypothesis 1 (H1). Corporate strategy and enterprise innovation have an inverted U-shaped nonlinear relationship. There is an inflection point (the inflection point is the point at which innovation performance is the lowest) before the turning point, prior to which corporate strategy can promote enterprise innovation activities. After the inflection point, the company strategy restrains the enterprise innovation activities.

\subsection{Mediating Effect of Corporate Risk-Taking}

Corporate strategy affects corporate risk-taking. The corporate risk-taking level reflects the degree of preference for risk and the degree of risk control [10,30]. A higher level of risk-taking can stimulate a company's potential and help it to gain long-term competitive advantages. Corporate strategy determines the direction of business activities, which may strongly affect corporate risk-taking [31]. According to the higher-order theory, the personal characteristics of the management have an important impact on corporate risk-taking [10,32]. Corporate strategy is mainly formulated and implemented by managers (especially chairmen and CEOs) and reflects the venture capital choices and preferences of enterprise managers to some extent $[33,34]$. Research shows that corporate strategy 
has an important impact on corporate risk-taking [21,35]. In order to gain competitive advantages, managers may tend to adopt aggressive business behaviors, such as investing in high-risk and high-yield projects, developing new products, opening up new markets and avoiding imitating and following the innovation strategies of competitors in the same industry [36]. This inevitably increases a company's investment risk and enhances the company's risk-taking level. However, enterprises adopting a conservative strategy tend to maintain the existing product market, pay more attention to product services and efficiency and maintain steady growth in enterprise performance. They will generally choose projects with low risk that provide stable income. They are thus confronted with controllable risk, which reduces the level of corporate risk-taking.

Existing research on corporate risk-taking and corporate innovation presents a series of research results but has not yet formed a unified consensus. By examining and summarizing some of the research on corporate risk and innovation (see Table 1), we found that scholars generally believe that corporate risk-taking has an important impact on corporate innovation activities.

Table 1. Research on risk and innovation.

\begin{tabular}{|c|c|c|}
\hline Dimension & Research Conclusion & Source \\
\hline \multirow{4}{*}{ Positive } & Market related risk promotes green technology innovation & [11] \\
\hline & Managers prone to risk-taking behaviors are more likely to obtain better innovation results & [12] \\
\hline & Organizational risk aversion has a positive impact on service innovation & [37] \\
\hline & Positive association between corporate risk-taking and future firm value & [38] \\
\hline \multirow{3}{*}{ Negative } & $\begin{array}{l}\text { High degrees of uncertainty in technologies and markets bring about high risks, resulting in } \\
\text { many technological innovation failures }\end{array}$ & [11] \\
\hline & Risk taking negatively affects green technology innovation performance & [30] \\
\hline & A negative relationship between risk-taking behavior and future performances & [39] \\
\hline \multirow{3}{*}{ Uncertainty } & $\begin{array}{c}\text { When perceived environmental uncertainty increases, companies tend to take risks associated } \\
\text { with innovation }\end{array}$ & [30] \\
\hline & $\begin{array}{l}\text { During the introductory and declining maturation stages, organizations tend to take higher risks, } \\
\text { and there is an adverse relationship between corporate risk-taking and operating performance, } \\
\text { whereas the growth and mature stages are opposite }\end{array}$ & [35] \\
\hline & $\begin{array}{c}\text { Companies tend to adopt non-green technology innovation with low risks when the level of risk } \\
\text { taking is high }\end{array}$ & [40] \\
\hline
\end{tabular}

Based on the perspective of agency theory and the perspective of information asymmetry, we believe that corporate risk-taking can improve corporate innovation performance. On the one hand, from the perspective of agency theory, the corporate risk-taking level is affected by many factors, such as external systems, corporate governance, and managerial characteristics; in particular, the willingness of corporate managers to take risks strongly affects the level of corporate risk-taking [29,30]. The existing research on the willingness to take risks is mainly based on the entrusted-agent framework, maintaining that the objective functions of corporate managers can be inconsistent with the maximization of shareholder corporate value. Managers tend to avoid innovation activities with high risk due to career planning, the pressure of business performance assessments and the threats of enterprise acquisition, etc., and their willingness to take risks is lower [11,33]. Research has shown that risk-taking can reduce the conservatism of managers' operations, thus reducing agency costs $[29,34]$. In general, enterprises with higher risk-taking levels have stronger dynamic abilities to face environmental uncertainty [30], which can effectively improve managers' tolerance of failure risk, relieve their professional anxiety, reduce agency problems and improve enterprises' willingness to take risks, thereby encouraging them to make independent innovation decisions and improve enterprise innovation performance by increasing innovation investment. On the other hand, from the information asymmetry perspective, corporate risk-taking can be recognized by the market as a positive signal, which can significantly increase the value of a company $[34,38]$. Therefore, companies 
with high levels of risk-taking are more willing to actively disclose certain important information, which helps investors and external intermediaries to understand the behavior of the managers and internal operations of the company in a timely fashion; this prevents information asymmetry and effectively clarifies any agency problems and moral hazards that may arise in the process of a manager's innovative investments, improving corporate internal governance [34]. At the same time, the level of corporate risk-taking reflects the degree of trust between shareholders and managers to a certain extent [12,38]. A higher level of corporate risk-taking can generally improve the independent decision-making power of corporate management and encourage managers to continue to focus on strategic investment decisions for the long-term development of their companies, such as innovative R\&D investments, so as to increase enterprise innovation performance. In addition, companies with higher levels of risk-taking may have better abilities and efficiency in using information, allowing them to respond to the changes in the external environment in a timely manner, which can enhance their environmental adaptability and improve innovation performance.

According to the above analysis, there is a plausible mechanism by which corporate strategy can influence enterprise innovation; that is, corporate strategy can affect corporate innovation performance by affecting the corporate risk-taking. Based on the above analysis, this paper proposes the following hypothesis:

Hypothesis 2 (H2). Corporate risk-taking plays an intermediary role between corporate strategy and enterprise innovation.

\section{Data and Research Method}

\subsection{Data and Sample}

This article selected data for listed Shanghai and Shenzhen A-share manufacturing companies for 2008-2018, which were obtained from CSMAR, Wind and other databases. The main reason for choosing the data from 2008 to 2018 was that the company patent data available in the CSMAR and Wind was collected from 2007 and end in the first half of 2019. By referring to existing research methods, the following samples were deleted: (1) samples of * ST and ST companies, (2) samples with abnormal financial data (such as samples with net assets less than zero), (3) samples with missing relevant data. Through sample screening, annual observations for 3461 companies were eventually obtained. To eliminate the influence of extreme values, all continuous variables were winsorized at the $1 \%$ and $99 \%$ levels. Stata 15.0 was used to process the data.

Finally, this study obtained sample data for the 3461 manufacturing companies. Table 2 shows the top ten manufacturing industry samples and their proportions according to the industrial classification guidelines for listed companies from the China Securities Regulatory Commission in 2012. The number of sampled companies that were in the top ten manufacturing industries was 2606 , accounting for $75.29 \%$ of the total sample, which shows that the selected manufacturing industries were quite different. Among them, the pharmaceutical manufacturing industry (C27) covered the most companies, 477, accounting for $13.78 \%$. Wine, beverage and refined tea manufacturing (C15) was in tenth place, with 105 companies, accounting for 3.03\%. The number of samples outside the top ten manufacturing industries was 855 , accounting for $24.71 \%$ of the total manufacturing samples, as shown in Table 2.

In order to further illustrate the representativeness of the sample data, we calculated simple statistics regarding the equity nature of the sample enterprises (see Table 3). It can be seen from Table 3 that among the 3461 selected samples, there were 1596 stateowned enterprises, accounting for $46.11 \%$; 1468 private enterprises, accounting for $42.41 \%$; 175 foreign-funded enterprises, accounting for $5.06 \%$; and 222 other types of enterprises, accounting for $6.42 \%$. Thus, state-owned and private enterprises accounted for the majority, which reflects the general trends in the equity nature of Chinese manufacturing enterprises 
in recent years. Therefore, it can be considered that this was a representative sample of China's listed manufacturing enterprises.

Table 2. Number and proportion of the top ten manufacturing industry samples.

\begin{tabular}{ccccc}
\hline Industry Code & Industry & Quantity & Ranking & Proportion \\
\hline C27 & Pharmaceutical manufacturing & 477 & 1 & $13.78 \%$ \\
C38 & Electrical machinery and equipment manufacturing & 405 & 2 & $11.70 \%$ \\
C35 & Special equipment manufacturing & 403 & 3 & $11.64 \%$ \\
C26 & Chemical raw materials and chemical products manufacturing & 360 & 4 & $10.40 \%$ \\
C36 & Automotive Manufacturing & 207 & 5 & $5.98 \%$ \\
C34 & General equipment manufacturing & 203 & 6 & $5.87 \%$ \\
C30 & Non-metallic mineral products industry & 183 & 7 & $5.29 \%$ \\
C37 & Railway, shipbuilding, aerospace and other transportation & 132 & 8 & $3.81 \%$ \\
C32 & equipment manufacturing & 131 & 9 & $3.79 \%$ \\
C15 & Non-ferrous metal smelting and rolling processing industry & 105 & 10 & $3.03 \%$ \\
Other & Liquor, beverage and refined tea manufacturing & 855 & - & $24.71 \%$ \\
Total & Other industry & 3461 & - & $100 \%$ \\
\hline
\end{tabular}

Data source: The author compiled according to the 2012 industry classification of the China Securities Regulatory Commission.

Table 3. Equity nature of sample enterprises.

\begin{tabular}{ccc}
\hline Nature of Equity & Quantity (3461) & Proportion (100\%) \\
\hline Private enterprises & 1468 & $42.41 \%$ \\
State-owned enterprises (SOE) & 1596 & $46.11 \%$ \\
Foreign capital enterprises & 175 & $5.06 \%$ \\
Other enterprises & 222 & $6.42 \%$ \\
\hline
\end{tabular}

\subsection{Key Variables}

\subsubsection{Enterprise Innovation}

The existing empirical literature mainly describes the use of R\&D expenditure and enterprise patents to measure enterprise innovation performance [15]. Considering the uncertainty regarding the conversion of input into output [41] and the availability and accuracy of R\&D input data (Chinese firms only voluntarily disclose their R\&D expenditures), we used corporate patents to measure innovation performance. According to the contents of patents, the Patent Law of China divides them into three categories: invention patents, utility model patents, and design patents. Referring to the research of Sapra et al. [14], Fang et al. [42], and Pang and Wang [15], we used the number of enterprise patent applications to measure enterprise innovation performance; that is, $\mathrm{Ln}$ (the number of patent applications +1 ) was used to measure enterprise innovation. Meanwhile, in the robustness test, the number of company patents granted and the number of company invention patents applications were used to measure enterprise innovation.

\subsubsection{Corporate Strategy}

According to the research of Bentley et al. [18] and Navissi et al. [20], we constructed a discrete variable for corporate strategy based on six aspects: new product development capability (R\&D expenditure as a percentage of operating income), service capability (the ratio of the number of employees to operating income), growth ability (the growth rate for the operating revenue), market expansion capability (the proportion of sales expenses and management expenses to operating income), organizational stability (employee volatility) and capital intensity (the proportion of fixed assets to total assets). The process was as follows: Firstly, the moving average values for the above six variables over the past five years were calculated. Then, the annual sample for each variable was divided into five groups, from small to large. For the first five variables, the maximum group was assigned 5 points, and the minimum group was assigned 1 point. The sixth variable was assigned 
in an opposite manner: the maximum and minimum groups were assigned 1 point and 5 points, respectively. Finally, the grouping scores for the six dimensions of each company annual sample were added to determine the corporate strategic aggressiveness, in the range of 6-30 points. The higher the score, the more aggressive of the company strategy.

\subsubsection{Corporate Risk-Taking}

With reference to the research of Faccio et al. [32], Habib and Hasan [21], and Shahzad et al. [35], the index of earnings volatility was used to measure the level of corporate risk-taking. Earnings volatility was measured according to the standard deviation of the return on assets (ROA). Firstly, in order to eliminate the impact of industry differences on the ROA, the industry average of the company's annual ROA was adjusted by taking the ROA of the enterprise in year T minus the average industry ROA in year T. Then, the standard deviation of the adjusted ROA of the enterprise during the observation period was calculated, which is the enterprise risk-taking level.

\subsubsection{Control Variables}

Referring to the research of Fang et al. [42], Pang and Wang [15], this study controlled some factors that have a significant impact on enterprise innovation as follows. (1) The company size (Size) is expressed as the natural logarithm of the number of employees of the company in the year. (2) The company age (Age) is expressed as the natural logarithm of the difference between the sample year and the company's registration year. (3) Dual: if the chairman and general manager of a company were the same person, it is 1; otherwise, it is 0. (4) Market process (Market): the marketization index compiled by Wang et al. [43] was used to measure the marketization process of the company's location. The value for the latest year was based on the moving average for the past three years. (5) Internal control (IControl) is expressed as the natural logarithm of the Shenzhen Dibo Internal Control Index. (6) Executive salary (Pay) is expressed as the natural logarithm of the average compensation of the top three executives. (7) The management shareholding ratio (Mshae) is expressed as the ratio of the number of management holdings to the total number of shares. (8) The TobinQ value (TobinQ) is expressed as the proportion of the company's market value in the total assets. (9) The asset liability ratio (DAR) is expressed as the ratio of total liabilities to total assets. (10) Financial leverage (Lev) is reflected by the proportion of the total of the three items of net profit, income tax expenses and financial expenses in the total of the two items of net profit and income tax expenses. In addition, the annual dummy variable and industry dummy variable were controlled in order to eliminate the influence of the time factor and industry factor on strategic change.

\subsection{Econometric Models}

In order to test hypothesis $\mathrm{H} 1$, that the relationship between corporate strategy and enterprise innovation performance is nonlinear, the following regression model was constructed.

$$
\text { Patent }=\alpha_{0}+\alpha_{1} \text { Strategy }+\alpha_{2} \text { Strategy } y^{2}+\sum \alpha_{i} \text { Control }+\varepsilon
$$

$\alpha_{0}$ represents the intercept term; $\alpha_{1}, \alpha_{2}$, and $\alpha_{i}$ represent regression coefficients; Control is the control variable; and $\varepsilon$ represents the error term. Patent means patent applications, Strategy means company strategy, and Strategy ${ }^{2}$ is the square of the company strategy. If the coefficient of $\alpha_{1}$ is significantly positive and the coefficient of $\alpha_{2}$ is significantly negative, it means that $t$ there is an inverted $U$-shaped nonlinear relationship between corporate strategy and enterprise innovation.

Referring to the hierarchical regression analysis method proposed by Baron and Kenny [44] and Wang et al. [45], the mediating effect of corporate risk-taking on the inverted U-shaped relationship between corporate strategy and enterprise innovation was 
tested in three steps. Hypothesis $\mathrm{H} 2$, the following model was constructed on the basis of Model (1).

$$
\begin{gathered}
\text { Risk }=\beta_{0}+\beta_{1} \text { Strategy }+\beta_{2} \text { Strategy }^{2}+\sum \beta_{i} \text { Control }+\varepsilon \\
\text { Patent }=\lambda_{0}+\lambda_{1} \text { Strategy }+\lambda_{2} \text { Strategy }^{2}+\lambda_{3} \text { Risk }+\sum \lambda_{i} \text { Control }+\varepsilon
\end{gathered}
$$

$\beta_{0}$ and $\lambda_{0}$ are constant terms. $\beta_{1}, \beta_{2}, \lambda_{1}, \lambda_{2}$ and $\lambda_{3}$ represent regression coefficients; Risk means enterprise risk-taking level. Control is the control variable, and $\varepsilon$ represents the error term.

\section{Empirical Analysis Results}

\subsection{Descriptive Statistics and Correlation Analysis}

Table 4 shows the descriptive statistics for the main variables; it can be seen from Table 4 that the numbers of patent applications from various enterprises vary greatly. The maximum natural logarithm of the number of enterprises patent applications is 6.9, the minimum is 0.693 , and the average is 3.293 , indicating large differences in the output of innovation achievements of Chinese manufacturing enterprises. The maximum value for company strategy is 28 , and the minimum value is 8 . The average, quartile and median values are 17.987, 15 and 18, respectively, indicating that the corporate strategies adopted by different listed manufacturing companies are quite different, and a large proportion of companies adopt more aggressive corporate strategies. The average level of corporate risk-taking is 0.025 , and the maximum, median and minimum values are $0.149,0.019$ and 0.002 , respectively, indicating that the risk-taking levels of most listed manufacturing companies are still low.

Table 4. Descriptive statistics.

\begin{tabular}{cccccccccc}
\hline Variables. & Sample & Average & Maximum & Minimum & SD & Variance & $\mathbf{2 5 \%}$ & Median & $\mathbf{7 5 \%}$ \\
\hline Patent & 3461 & 3.293 & 6.9 & 0.693 & 1.351 & 1.826 & 2.303 & 3.258 & 4.159 \\
Strategy & 3461 & 17.987 & 28 & 8 & 4.488 & 20.139 & 15 & 18 & 21 \\
Strategy $^{2}$ & 3461 & 343.655 & 784 & 64 & 162.797 & 26,503 & 225 & 324 & 441 \\
Risk & 3461 & 0.025 & 0.149 & 0.002 & 0.023 & 0.001 & 0.011 & 0.019 & 0.03 \\
Dual & 3461 & 0.21 & 1 & 0 & 0.407 & 0.166 & 0 & 0 & 0 \\
Size & 3461 & 7.995 & 10.929 & 5.583 & 1.134 & 1.287 & 7.163 & 7.954 & 8.741 \\
Age & 3461 & 2.717 & 3.332 & 1.609 & 0.323 & 0.104 & 2.565 & 2.773 & 2.944 \\
Market & 3461 & 7.594 & 9.88 & 2.59 & 1.811 & 3.279 & 6.36 & 7.81 & 9.35 \\
IControl & 3461 & 669.802 & 922.01 & 0 & 115.197 & $13,270.44$ & 639.41 & 681.69 & 714.74 \\
Mshare & 3461 & 0.092 & 0.639 & 0 & 0.17 & 0.029 & 0 & 0 & 0.085 \\
Pay & 3461 & 13.095 & 14.928 & 11.53 & 0.688 & 0.473 & 12.64 & 13.076 & 13.533 \\
TobinQ & 3461 & 2.085 & 8.687 & 0.235 & 1.636 & 2.676 & 0.917 & 1.629 & 2.717 \\
DAR & 3461 & 0.439 & 0.87 & 0.066 & 0.193 & 0.037 & 0.288 & 0.444 & 0.592 \\
Lev & 3461 & 1.621 & 10.308 & 0.385 & 1.474 & 2.172 & 1.007 & 1.131 & 1.546 \\
\hline
\end{tabular}

Source: According to the running results of Stata15.0; Strategy ${ }^{2}$ is the square of the company strategy (the same as in the table below).

Table 5 shows the correlation analysis results for the main variables, and it can be seen that there is a significant correlation between the variables. In addition, the independent variables were tested for the potential problem of collinearity according to the variance inflation factor (VIF); all the VIFs were significantly below 10, excluding influence from multicollinearity. 
Table 5. Correlation analysis results of main variables.

\begin{tabular}{|c|c|c|c|c|c|c|c|c|c|c|c|c|c|c|}
\hline Variables & Patent & Strategy & Strategy $^{2}$ & Risk & Dual & Size & Age & Market & IControl & Mshare & Pay & TobinQ & DAR & Lev \\
\hline Patent & 1.000 & & & & & & & & & & & & & \\
\hline Strategy & $0.027^{* * *}$ & 1.000 & & & & & & & & & & & & \\
\hline Strategy $^{2}$ & $-0.028 * *$ & $0.989^{* * *}$ & 1.000 & & & & & & & & & & & \\
\hline Risk & $-0.095^{* * *}$ & $0.021^{* *}$ & $-0.018^{* *}$ & 1.000 & & & & & & & & & & \\
\hline Dual & -0.023 & $0.126^{* * *}$ & $0.131^{* * *}$ & -0.031 * & 1.000 & & & & & & & & & \\
\hline Size & $0.473^{* * *}$ & $\underset{* * *}{-0.262}$ & $\underset{* * *}{-0.261}$ & $\underset{* * *}{-0.045}$ & $\underset{* * *}{-0.134}$ & 1.000 & & & & & & & & \\
\hline Age & 0.028 * & $\underset{* * *}{-0.098}$ & $\underset{* * *}{-0.098}$ & 0.025 & -0.016 & $0.135^{* * *}$ & 1.000 & & & & & & & \\
\hline Market & $0.148^{* * *}$ & 0.011 & 0.004 & $\underset{* * *}{-0.100}$ & $0.141^{* * *}$ & $\underset{* * *}{-0.118}$ & $0.094^{* * *}$ & 1.000 & & & & & & \\
\hline IControl & $0.099 * * *$ & $\underset{* * *}{-0.083}$ & $\underset{* * *}{-0.078}$ & $-\underset{* * *}{0.107}$ & -0.024 & $0.201^{* * *}$ & $\underset{* * *}{-0.117}$ & 0.013 & 1.000 & & & & & \\
\hline Mshare & $-0.084^{* * *}$ & $0.263^{* * *}$ & $0.273^{* * *}$ & $\underset{* * *}{-0.085}$ & $0.282^{* * *}$ & $\underset{* * *}{-0.393}$ & $\underset{* * *}{-0.192}$ & $0.218^{* * *}$ & $\underset{* * *}{-0.056}$ & 1.000 & & & & \\
\hline Pay & $0.310^{* * *}$ & $\underset{* * *}{-0.120}$ & $\underset{* * *}{-0.130}$ & $\underset{* * *}{-0.053}$ & $0.057^{* * *}$ & $0.341^{* * *}$ & $0.188^{* * *}$ & $0.225^{* * *}$ & $0.132 * * *$ & $\underset{* * *}{-0.046}$ & 1.000 & & & \\
\hline TobinQ & $-0.185^{* * *}$ & $0.313^{* * *}$ & $0.306^{* * *}$ & $0.050^{* * *}$ & $0.132 * * *$ & $-\underset{* * *}{0.439}$ & $-0.039 * *$ & $0.122^{* * *}$ & $-0.043^{* *}$ & $0.344^{* * *}$ & -0.010 & 1.000 & & \\
\hline DAR & $0.224^{* * *}$ & $-\underset{* * *}{-0.288}$ & $-\underset{* * *}{0.288}$ & 0.025 & $-\underset{* * *}{0.157}$ & $0.480^{* * *}$ & $0.068^{* * *}$ & $-\underset{* * *}{0.201}$ & 0.028 & $\underset{* * *}{-0.379}$ & $0.040^{* *}$ & $\underset{* * *}{-0.534}$ & 1.000 & \\
\hline Lev & $-0.047^{* * *}$ & $\underset{* * *}{-0.163}$ & $-\underset{* * *}{-0.150}$ & $0.040^{* *}$ & $\underset{* * *}{-0.081}$ & $0.157^{* * *}$ & 0.024 & $\underset{* * *}{-0.169}$ & $-\underset{* * *}{-0.122}$ & $\underset{* * *}{-0.151}$ & $\underset{* * *}{-0.166}$ & $\underset{* * *}{-0.271}$ & $0.416^{* * *}$ & 1.000 \\
\hline
\end{tabular}




\subsection{Regression Results}

Table 6 reports the regression results. The results for Models (1) and (2) show an impact of corporate strategy on enterprise innovation. Model (1) is the regression result of the control variables against enterprise innovation. In Model (2), corporate strategy and the square of corporate strategy are added, and the regression results show that the coefficient for corporate strategy is significantly positive $(\alpha 1=0.037, p<0.01)$, while the coefficient for the square term of corporate strategy is significantly negative $(\alpha 2=-0.012$, $p<0.05$ ), indicating that there is an inverted U-shaped nonlinear relationship between corporate strategy and enterprise innovation. In other words, lower corporate strategy can promote enterprise innovation, but as corporate strategy becomes more and more aggressive, it tends to inhibit enterprise innovation performance when it exceeds a certain level. Hypothesis H1 was thus verified.

Table 6. Regression results of corporate strategy, corporate risk-taking and enterprise innovation.

\begin{tabular}{|c|c|c|c|c|}
\hline Variables & $\begin{array}{c}\text { Model (1) } \\
\text { Patent }\end{array}$ & $\begin{array}{c}\text { Model (2) } \\
\text { Patent }\end{array}$ & $\begin{array}{c}\text { Model (3) } \\
\text { Risk }\end{array}$ & $\begin{array}{c}\text { Model (4) } \\
\text { Patent }\end{array}$ \\
\hline Strategy & & $\begin{array}{c}0.037^{* * *} \\
(0.005)\end{array}$ & $\begin{array}{c}0.035^{* * *} \\
(0.008)\end{array}$ & $\begin{array}{c}0.038^{* * *} \\
(0.005)\end{array}$ \\
\hline Strategy $^{2}$ & & $\begin{array}{c}-0.012 * * \\
(0.021)\end{array}$ & $\begin{array}{c}-0.011 \text { ** } \\
(0.016)\end{array}$ & $\begin{array}{c}-0.015^{* * *} \\
(0.017)\end{array}$ \\
\hline Risk & & & & $\begin{array}{c}-0.276^{* * *} \\
(0.137)\end{array}$ \\
\hline $\begin{array}{c}\text { Control } \\
\text { variables }\end{array}$ & control & control & control & control \\
\hline _cons & $\begin{array}{c}-5.071^{* * *} \\
(0.460)\end{array}$ & $\begin{array}{c}-5.478^{* * *} \\
(0.484)\end{array}$ & $\begin{array}{c}-4.048^{* * *} \\
(0.410)\end{array}$ & $\begin{array}{c}-4.426^{* * *} \\
(0.439)\end{array}$ \\
\hline Year & control & control & control & control \\
\hline Industry & control & control & control & control \\
\hline $\mathrm{N}$ & 3461 & 3461 & 3461 & 3461 \\
\hline R-squared & 0.2316 & 0.2315 & 0.2167 & 0.2517 \\
\hline
\end{tabular}

The results for Models (2) to (4) show the mediating effect of enterprise risk-taking on the inverted U-shaped relationship between corporate strategy and enterprise innovation. Model (3) is the regression result for the influence of corporate strategy on enterprise risk-taking, and Model (4) is the regression result when adding intermediate variables on the basis of Model (2). Firstly, the coefficients $\alpha_{1}, \beta_{1}$ and $\lambda_{1}$ of corporate strategy in Model (2) to (4) are significantly positive $\left(\alpha_{1}=0.037, p<0.01 ; \beta_{1}=0.035, p<0.01\right.$; $\left.\lambda_{1}=0.038, p<0.01\right)$, indicating that corporate strategy has a significant impact on corporate risk-taking and enterprise innovation. Secondly, in Models (2) to (4), the coefficients $\alpha_{2}, \beta_{2}$ and $\lambda_{2}$ of the square term of the company strategy are all significantly negative $\left(\alpha_{2}=-0.012\right.$, $\left.p<0.05 ; \beta_{2}=-0.011, p<0.05 ; \lambda_{2}=-0.015, p<0.01\right)$. Finally, in the intermediary Model (4), the coefficient $\lambda_{3}$ for corporate risk-taking is significantly negative $\left(\lambda_{2}=-0.276, p<0.01\right)$, and the results show that corporate risk-taking partly mediates the inverted U-shaped relationship between corporate strategy and enterprise innovation.

\subsection{Grouping Test for the Nature of Enterprise Property Rights}

In order to further elucidate the characteristics of enterprise property rights, the samples were divided into state-owned and non-state-owned enterprises according to enterprise property rights for a grouping test. The results are shown in Table 7 . In the regression results for the sample of state-owned enterprises, the coefficient for corporate strategy in Model (1) is significantly positive $\left(\alpha_{1}=0.071, p<0.05\right)$, and the coefficient for the square term of corporate strategy is significantly negative $\left(\alpha_{2}=-0.014, p<0.05\right)$, indicating that there is an inverted U-shaped nonlinear relationship between corporate strategy and enterprise innovation in state-owned enterprises. According to the Model (1) to (3), 
$\alpha_{1}, \beta_{1}$ and $\lambda_{1}$ are all significantly positive, while $\alpha_{2}, \beta_{2}, \lambda_{2}$ and $\lambda_{3}$ are all significantly negative, suggesting that corporate risk-taking partially mediates the inverted U-shaped relationship between corporate strategy and enterprise innovation, and the regression results for the state-owned enterprises are consistent with those for the full sample. In the regression results for the sample of non-state-owned enterprises, the coefficient for corporate strategy in Model (1) is significantly positive $\left(\alpha_{1}=0.046, p<0.05\right)$, and the coefficient for the square term of corporate strategy is significantly negative $\left(\alpha_{2}=-0.011\right.$, $p<0.05)$, indicating that there is an inverted $\mathrm{U}$-shaped nonlinear relationship between corporate strategy and enterprise innovation in non-state-owned enterprises. However, in Model (2), the coefficient for corporate strategy is 0.026 , and the coefficient for the square term of corporate strategy is -0.018 , both of which are not significant. The coefficient for enterprise risk-taking in Model (3) is -1.551 , which is also not significant. This shows that in the sample of non-state-owned enterprises, corporate risk-taking does not mediate the inverted U-shaped relationship between corporate strategy and enterprise innovation, which is confirmed by the Sobel test results $(Z=2.348, p>0.1)$. Therefore, it can be said that the impact of corporate strategy on enterprise innovation is mediated through corporate risk-taking only in state-owned enterprises. This may be due to the stricter supervision of the state-owned assets in state-owned enterprises. In non-state-owned enterprises, corporate risk-taking has relatively little effect on enterprise innovation performance and may not be the key factor for enterprise managers to consider when making innovation investment decisions.

Table 7. Grouping test results by property right.

\begin{tabular}{|c|c|c|c|c|c|c|}
\hline \multirow[b]{2}{*}{ Variables } & \multicolumn{3}{|c|}{ State-Owned Enterprise Group } & \multicolumn{3}{|c|}{ Non-State-Owned Enterprise Group } \\
\hline & $\begin{array}{c}\text { Model (1) } \\
\text { Patent }\end{array}$ & $\begin{array}{c}\text { Model (2) } \\
\text { Risk }\end{array}$ & $\begin{array}{c}\text { Model (3) } \\
\text { Patent }\end{array}$ & $\begin{array}{c}\text { Model (1) } \\
\text { Patent }\end{array}$ & $\begin{array}{c}\text { Model (2) } \\
\text { Risk }\end{array}$ & $\begin{array}{c}\text { Model (3) } \\
\text { Patent }\end{array}$ \\
\hline Strategy & $\begin{array}{c}0.071^{* *} \\
(0.037)\end{array}$ & $\begin{array}{l}0.012 * * \\
(0.021)\end{array}$ & $\begin{array}{c}0.072 * * * \\
(0.037)\end{array}$ & $\begin{array}{c}0.046^{* *} \\
(0.036)\end{array}$ & $\begin{array}{c}0.026 \\
(0.063)\end{array}$ & $\begin{array}{c}0.074^{* * *} \\
(0.056)\end{array}$ \\
\hline Strategy ${ }^{2}$ & $\begin{array}{c}-0.014 \\
(0.016)\end{array}$ & $\begin{array}{c}-0.006^{* *} \\
(0.011)\end{array}$ & $\begin{array}{c}-0.012 * * \\
(0.015)\end{array}$ & $\begin{array}{c}-0.011^{* *} \\
(0.012)\end{array}$ & $\begin{array}{l}-0.018 \\
(0.008)\end{array}$ & $\begin{array}{c}-0.016^{* *} \\
(0.012)\end{array}$ \\
\hline Risk & & & $\begin{array}{c}-0.247^{* *} \\
(0.842)\end{array}$ & & & $\begin{array}{l}-1.551 \\
(0.925)\end{array}$ \\
\hline Control variables & control & control & control & control & control & control \\
\hline _cons & $\begin{array}{c}-5.402^{* * *} \\
(0.441)\end{array}$ & $\begin{array}{c}0.103^{* * *} \\
(0.019)\end{array}$ & $\begin{array}{c}-5.427^{* * *} \\
(0.746)\end{array}$ & $\begin{array}{c}-5.082^{* * *} \\
(0.466)\end{array}$ & $\begin{array}{c}0.073^{* * *} \\
(0.018)\end{array}$ & $\begin{array}{c}-5.354^{* * *} \\
(0.757)\end{array}$ \\
\hline Year & control & control & control & control & control & control \\
\hline Industry & control & control & control & control & control & control \\
\hline $\mathrm{N}$ & 1596 & 1596 & 1596 & 1865 & 1865 & 1865 \\
\hline R-squared & 0.2759 & 0.035 & 0.2761 & 0.1899 & 0.1899 & 0.1939 \\
\hline
\end{tabular}

Source: According to the results of stata15.0. ${ }^{* * *} p<0.01{ }^{* *} p<0.05$. The values in parentheses are standard errors.

\subsection{Robustness Check}

The endogeneity problem often exists in empirical research, which is caused by missing variables, reverse causality or measurement errors $[15,46]$. In order to avoid the impact of the endogeneity problem on the results of this study, we adopted the following methods:

Firstly, the instrumental variable approach. Corporate strategy and enterprise innovation may also be affected by some company-level factors, such as innovation culture, manager characteristics, organizational structure, and government regulations. Therefore, the relationship between corporate strategy and enterprise innovation may be caused by missing variables; that is, there are endogenous problems. In order to alleviate the impact of endogeneity on the conclusion, this article uses the instrumental variable approach to control the endogeneity problem. We took the one-period-lagging and two-period-lagging corporate strategy and the square term of the corporate strategy as exogenous instrumental variables, and a regression model was established to re-estimate the impact of corporate strategy on enterprise innovation. The regression results are shown in Table 8, where it 
can be observed that the two-stage model fits well, and the weak instrumental variables show that corporate strategy and the square term of corporate strategy with one- and two-periods lag are significantly correlated with the current corporate strategy, at the $5 \%$ level. According to the second-stage regression results, after controlling endogeneity, corporate strategy was still shown to have a significant impact on enterprise innovation, which further verifies the research hypothesis of this paper. Secondly, the substitution tests were conducted for the enterprise innovation indicators. The enterprise innovation level was measured by the numbers of company patents granted and company invention-patent applications. The regression results are shown in Table 9. Third, in order to eliminate the influence of company characteristics on the research results, this study further adopted a fixed effect model to mitigate the interference of company-level factors on the research conclusions. The regression results of the fixed effects model are shown in Table 10. The results showed that the coefficient of corporate strategy is still significantly positive at the $1 \%$ level, and corporate strategy ${ }^{2}$ is still significantly negative at the $5 \%$ level, indicating that the conclusions are still robust after controlling for company-level characteristics. The empirical results of the above robustness test are basically consistent with the aforementioned empirical results, which confirms the robustness of our research results.

Table 8. Two-stage least squares regression results.

\begin{tabular}{|c|c|c|c|}
\hline Variables & The First Stage (Strategy) & The First Stage (Strategy) & The Second Stage (Patent) \\
\hline Strategy $(\mathrm{t}-1)$ & $0.685^{* * *}$ & $\begin{array}{l}0.745^{* * *} \\
(0116)\end{array}$ & \\
\hline Strategy $^{2}(\mathrm{t}-1)$ & & $\begin{array}{c}-0.002 \\
(0.003)\end{array}$ & \\
\hline Strategy (t-2) & $\begin{array}{c}0.135 * * * \\
(0.023)\end{array}$ & $\begin{array}{l}0.268^{* *} \\
(0.117)\end{array}$ & \\
\hline Strategy $^{2}(\mathrm{t}-2)$ & & $\begin{array}{c}-0.004^{* *} \\
(0.003)\end{array}$ & \\
\hline Strategy & & & $\begin{array}{c}0.018^{* *} \\
(0.028)\end{array}$ \\
\hline Strategy $^{2}$ & & & $\begin{array}{c}-0.003^{* * *} \\
(0.001)\end{array}$ \\
\hline Control variables & control & control & control \\
\hline _cons & $\begin{array}{c}5.801^{* * *} \\
(1.313)\end{array}$ & $\begin{array}{c}4.482^{* * *} \\
(1.469)\end{array}$ & $\begin{array}{c}-4.788^{* * *} \\
(0.498)\end{array}$ \\
\hline Year & control & control & control \\
\hline Industry & control & control & control \\
\hline R-squared & 0.703 & 0.704 & 0.309 \\
\hline $\mathrm{N}$ & 1826 & 1826 & 3461 \\
\hline $\mathrm{F}$ & 357.95 & 307.45 & 119.15 \\
\hline Prob $>$ chi 2 & 0.000 & 0.0000 & 0.0000 \\
\hline
\end{tabular}

Source: According to the results of stata15.0; (t-1) and (t-2) represent the data of one-period-lagging and two-period-lagging, respectively; ${ }^{* * *} p<0.01,{ }^{* *} p<0.05$. The values in parentheses are standard errors.

Table 9. Regression results of substitution test of enterprise innovation indicators.

\begin{tabular}{|c|c|c|c|c|c|c|}
\hline \multirow[b]{2}{*}{ Variables } & \multicolumn{3}{|c|}{ Number of Patents Granted } & \multicolumn{3}{|c|}{ Number of Invention Patent Applications } \\
\hline & $\begin{array}{c}\text { Model (1) } \\
\text { Patent }\end{array}$ & $\begin{array}{c}\text { Model (2) } \\
\text { Risk }\end{array}$ & $\begin{array}{c}\text { Model (3) } \\
\text { Patent }\end{array}$ & $\begin{array}{c}\text { Model (1) } \\
\text { Patent }\end{array}$ & $\begin{array}{c}\text { Model (2) } \\
\text { Risk }\end{array}$ & $\begin{array}{c}\text { Model (3) } \\
\text { Patent }\end{array}$ \\
\hline Strategy & $\begin{array}{c}0.021 * * * \\
(0.029)\end{array}$ & $\begin{array}{c}0.035^{* * *} \\
(0.008)\end{array}$ & $\begin{array}{c}0.021^{* * * *} \\
(0.029)\end{array}$ & $\begin{array}{c}0.793 * * * \\
(0.383)\end{array}$ & $\begin{array}{c}0.032 \text { *** } \\
(0.012)\end{array}$ & $\begin{array}{c}0.708^{* * *} \\
(2.381)\end{array}$ \\
\hline Strategy $^{2}$ & $\begin{array}{c}-0.010^{* *} \\
(0.021)\end{array}$ & $\begin{array}{c}-0.011^{* *} \\
(0.016)\end{array}$ & $\begin{array}{c}-0.015^{* * *} \\
(0.017)\end{array}$ & $\begin{array}{c}-0.021^{* * *} \\
(0.063)\end{array}$ & $\begin{array}{c}-0.015^{* *} \\
(0.018)\end{array}$ & $\begin{array}{c}-0.018^{* * * *} \\
(0.063)\end{array}$ \\
\hline Risk & & & $\begin{array}{c}-0.442^{* * *} \\
(0.701)\end{array}$ & & & $\begin{array}{c}-0.336^{* *} \\
(0.699)\end{array}$ \\
\hline
\end{tabular}


Table 9. Cont.

\begin{tabular}{|c|c|c|c|c|c|c|}
\hline \multirow[b]{2}{*}{ Variables } & \multicolumn{3}{|c|}{ Number of Patents Granted } & \multicolumn{3}{|c|}{ Number of Invention Patent Applications } \\
\hline & $\begin{array}{c}\text { Model (1) } \\
\text { Patent }\end{array}$ & $\begin{array}{c}\text { Model (2) } \\
\text { Risk }\end{array}$ & $\begin{array}{c}\text { Model (3) } \\
\text { Patent }\end{array}$ & $\begin{array}{l}\text { Model (1) } \\
\text { Patent }\end{array}$ & $\begin{array}{l}\text { Model (2) } \\
\text { Risk }\end{array}$ & $\begin{array}{c}\text { Model (3) } \\
\text { Patent }\end{array}$ \\
\hline $\begin{array}{c}\text { Control } \\
\text { variables }\end{array}$ & control & control & control & control & control & control \\
\hline _cons & $\begin{array}{c}-3.119 \text { *** } \\
(0.544)\end{array}$ & $\begin{array}{c}-4.048^{* * *} \\
(0.410)\end{array}$ & $\begin{array}{c}-3.086 \text { *** } \\
(0.547)\end{array}$ & $\begin{array}{c}-4.138^{* * *} \\
(0.826)\end{array}$ & $\begin{array}{c}0.077^{* * *} \\
(0.014)\end{array}$ & $\begin{array}{c}-4.046^{* * *} \\
(0.4843)\end{array}$ \\
\hline Year & control & control & control & control & control & control \\
\hline Industry & control & control & control & control & control & control \\
\hline $\mathrm{N}$ & 3461 & 3461 & 3461 & 2722 & 2722 & 2722 \\
\hline R-squared & 0.2538 & 0.2167 & 0.2549 & 0.1468 & 0.1514 & 0.1906 \\
\hline
\end{tabular}

Source: According to the results of stata15.0. ${ }^{* * *} p<0.01,{ }^{* *} p<0.05$. The values in parentheses are standard errors. Due to the lack of invention patent data of many listed companies, the sample data is 2722 .

Table 10. Robustness test: fixed effect model.

\begin{tabular}{|c|c|c|c|c|}
\hline Variables & $\begin{array}{c}\text { Model (1) } \\
\text { Patent }\end{array}$ & $\begin{array}{c}\text { Model (2) } \\
\text { Patent }\end{array}$ & $\begin{array}{c}\text { Model (3) } \\
\text { Risk }\end{array}$ & $\begin{array}{c}\text { Model (4) } \\
\text { Patent }\end{array}$ \\
\hline Strategy & & $\begin{array}{c}0.040^{* *} \\
(0.027)\end{array}$ & $\begin{array}{c}0.015^{* *} \\
(0.012)\end{array}$ & $\begin{array}{c}0.041^{* *} \\
(0.027)\end{array}$ \\
\hline Strategy $^{2}$ & & $\begin{array}{c}-0.011 \text { * } \\
(0.021)\end{array}$ & $\begin{array}{c}-0.008^{* *} \\
(0.018)\end{array}$ & $\begin{array}{c}-0.014 \text { * } \\
(0.022)\end{array}$ \\
\hline Risk & & & & $\begin{array}{c}-0.149 * * \\
(0.630)\end{array}$ \\
\hline Control variables & control & control & control & control \\
\hline _cons & $\begin{array}{c}-3.985^{* * *} \\
(0.469)\end{array}$ & $\begin{array}{c}-4.283^{* * *} \\
(0.543)\end{array}$ & $\begin{array}{c}0.482^{* * *} \\
(0.016)\end{array}$ & $\begin{array}{c}-4.295^{* * *} \\
(0.546)\end{array}$ \\
\hline Year & control & control & control & control \\
\hline $\mathrm{N}$ & 3461 & 3461 & 3461 & 3461 \\
\hline F-statistic & 11.11 & 10.89 & 6.99 & 10.84 \\
\hline Prob $>$ F & 0 & 0 & 0 & 0 \\
\hline R-squared & 0.247 & 0.248 & 0.129 & 0.248 \\
\hline
\end{tabular}

Source: According to the results of Stata15.0. Standard errors are in parenthesis. ${ }^{* * *} p<0.01,{ }^{* *} p<0.05,{ }^{*} p<0.1$.

\section{Conclusions}

This study selected data for listed Chinese A-share manufacturing companies for 2008 to 2018, and empirically tested the impact of corporate strategy on enterprise innovation and the potential mediating factor of corporate risk-taking. The findings were as follows. Firstly, corporate strategy and enterprise innovation show an inverted U-shaped nonlinear relationship, and there is an inflection point (the point at which the company's innovation performance is the lowest) before which corporate strategy can promote enterprise innovation; after this point, further corporate strategy inhibits enterprise innovation. Secondly, corporate risk-taking mediates the relationship between corporate strategy and innovation performance; that is, corporate strategy can affect corporate innovation performance by influencing corporate risk-taking levels. Finally, the mediating effect of enterprise risk-taking differs due to the heterogeneity of enterprise property rights; corporate risk-taking was more significant as a mechanism in corporate strategy's influence on corporate innovation in the sample of state-owned enterprises than in those not owned by the state. This may be due to the stricter supervision of the state-owned assets in state-owned enterprises. In non-state-owned enterprises, corporate risk-taking has relatively little effect on innovation performance, so when corporate managers make innovative investment decisions, corporate risk-taking may not be the key factors that needs to be considered. This study not only enriches and expands the knowledge about contextual variables and the mechanism by which corporate strategy affects enterprise innovation, but the conclusions reached can 
enlighten the managers of Chinese manufacturing enterprises to help them to make good decisions regarding innovation strategy.

The research conclusions have three main managerial implications for the innovation investment of manufacturing enterprises. First, corporate strategy can significantly affect innovation performance, and different corporate strategies have different impacts on innovation performance. Most strategic choices are made by managers based on bounded rationality; at present, the relevant experience and abilities of managers play an important role in the formulation and implementation of corporate strategic decisions, which requires managers to have certain strategic visions and to constantly improve their own professionalism and capabilities to improve the appropriateness and effectiveness of their innovative strategic investment decisions. Second, corporate risk-taking plays a part in mediating the influence of corporate strategy on innovation performance, and this effect was verified in state-owned enterprises. For non-state-owned enterprises, it is necessary to continuously improve corporate governance, reduce agency problems and moral hazards in the process of innovation investment, improve corporate risk-taking levels, and then enhance innovation performance. At the same time, managers should fully consider the differences between the external institutional environment and corporate strategic style when making corporate strategy choices and improve innovation performance through the appropriate matching of corporate strategic styles and corporate risk-taking levels. Third, lessons from the COVID-19 pandemic regarding strategic flexibility have important implications for the research conclusions of this paper. The COVID-19 crisis is a major challenge for all companies, and they have suffered losses of varying degrees. In the face of the fierce and turbulent external environment, enterprise managers should maintain strategic flexibility to improve their ability to deal with unknown risks and continuously improve their innovation capabilities through active participation. For example, responsible large-scale enterprises can improve their ability to respond to the epidemic in the future through vaccines and patents and continuously improve their governance and innovation capabilities by actively participating in the governance related to social public issues.

This research can be further expanded upon in the following aspects. First, this study empirically tested a mechanism by which corporate strategy could influence enterprise innovation, i.e., enterprise risk-taking. However, innovation culture, organization structure, government regulations, government regulations, external market competition, and external environmental factors were under-explored in our study, and they may have a significant impact on corporate risk-taking and innovation performance. These will be of great significance for future research into financial accounting and should help companies to choose appropriate corporate strategies and make reasonable investment decisions based on the allocation of limited resources, so as to optimize their financial behavior and performance. Second, companies tend to make different innovation investment decisions based on their strategic types. In the future, they may evaluate the appropriateness and effectiveness of different innovation investment options by examining whether they are beneficial for the realization of the company's strategic goals. For example, whether companies' rush for vaccines and patents is conducive to the realization of corporate strategy, thus improving the innovation performance of relevant enterprises, could be studied. Third, the external institutional environment is an important factor that affects enterprise innovation and strategic choices. However, to what extent does the matching of corporate strategy and the external environment optimize innovation performance? Based on the specific institutional environments of the transitional countries, studying the matching of corporate strategic style with institutional environment is also an important topic for future related research, which could provide an important reference for corporate innovation decision-making.

Finally, a few limitations should be mentioned. Firstly, we only focused on the end of the innovation process, patents, while ignoring the other stages. Future research could refer to the 82 unique innovation evaluation indicators summarized by Dziallas and Blind [26] at different stages of the innovation process to measure innovation performance 
in multiple dimensions and at multiple stages. Secondly, although we performed a series of robustness tests-group tests, the instrumental variable approach, variable substitution and a fixed effect test-showing that the research conclusions were relatively robust, the article lacks discussion of some unobserved factors that could influence the conclusions. Therefore, future research could explore further mechanisms by which corporate strategy may influence corporate innovation, such as managerial attributes, enterprise innovation culture, corporate governance factors and external institutional factors.

Author Contributions: R.L., Y.C. and Y.Z. conceptualized the research and designed the empirical framework; R.L. and Y.C. managed the data collection initiatives and writing; R.L. and Y.Z. conducted the empirical analysis and documented the findings. All authors have read and agreed to the published version of the manuscript.

Funding: This project received funding from the Special Fund project for basic Scientific research operating Expenses of Central Universities (2019YJS074).

Institutional Review Board Statement: Not applicable.

Informed Consent Statement: Not applicable.

Data Availability Statement: Not applicable.

Conflicts of Interest: The authors declare no conflict of interest.

\section{References}

1. Engert, S.; Baumgartner, R.J. Corporate sustainability strategy-bridging the gap between formulation and implementation. $J$. Clean. Prod. 2016, 113, 822-834. [CrossRef]

2. Baumgartner, R.J.; Rauter, R. Strategic perspectives of corporate sustainability management to develop a sustainable organization. J. Clean. Prod. 2017, 140, 81-92. [CrossRef]

3. Saunila, M.; Nasiri, M.; Ukko, J.; Rantala, T. Smart technologies and corporate sustainability: The mediation effect of corporate sustainability strategy. Comput. Ind. 2019, 108, 178-185. [CrossRef]

4. Parnell, J.A.; Long, Z.; Lester, D. Competitive strategy, capabilities and uncertainty in small and medium sized enterprises (SMEs) in China and the United States. Manage. Dec. 2015, 53, 402-431. [CrossRef]

5. Christensen, J.F. Corporate strategy and the management of innovation and technology. Ind. Corp. Chang. 2002, 11, 263-288. [CrossRef]

6. Kumar, K.; Boesso, G.; Favotto, F.; Menini, A. Strategic orientation, innovation patterns and performances of SMEs and large companies. J. Small Bus. Enterp. Dev. 2012, 19, 132-145. [CrossRef]

7. Prajogo, D.I.; Sohal, A.S. The relationship between organization strategy, total quality management (TQM), and organization performance: The mediating role of TQM. Eur. J. Oper. Res. 2006, 168, 35-50. [CrossRef]

8. Lau, C. Team and organizational resources, strategic orientations, and firm performance in a transitional economy. J. Bus. Res. 2011, 64, 1344-1351. [CrossRef]

9. Cingöz, A.; Akdoğan, A. Strategic flexibility, environmental dynamism, and innovation performance: An empirical study. Procedia-Soc. Behav. Sci. 2013, 99, 582-589. [CrossRef]

10. Li, J.; Tang, Y.I. CEO hubris and firm risk taking in china: The moderating role of managerial discretion. Acad. Manag. J. 2010, 53, 45-68. [CrossRef]

11. Roper, S.; Tapinos, E. Taking risks in the face of uncertainty: An exploratory analysis of green innovation. Technol. Forecast. Soc. Chang. 2016, 112, 357-363. [CrossRef]

12. García-Granero, A.; Llopis, S.; Fernández-Mesa, A.; Alegre, J. Unraveling the link between managerial risk-taking and innovation: The mediating role of a risk-taking climate. J. Bus. Res. 2015, 68, 1094-1104. [CrossRef]

13. Anderson, N.; Potočnik, K.; Zhou, J. Innovation and creativity in organizations: A state-of-the-science review, prospective commentary, and guiding framework. J. Manag. 2014, 40, 1297-1333. [CrossRef]

14. Sapra, H.; Subramanian, A.; Subramanian, K.V. Corporate governance and innovation: Theory and evidence. J. Financ. Quant. Anal. 2014, 49, 957-1003. [CrossRef]

15. Pang, C.; Wang, Y. Stock pledge, risk of losing control and corporate innovation. J. Corp. Financ. 2020. [CrossRef]

16. Rosing, K.; Frese, M.; Bausch, A. Explaining the heterogeneity of the leadership-innovation relationship: Ambidextrous leadership. Leadersh Q. 2011, 22, 956-974. [CrossRef]

17. Miles, R.E.; Snow, C.C. Organizational Strategy, Structure and Process; McGraw-Hill: New York, NY, USA, 1978.

18. Bentley, K.A.; Omer, T.C.; Sharp, N.Y. Business strategy, financial reporting irregularities, and audit effort. Contemp. Account. Res. 2013, 30, 780-817. [CrossRef]

19. Porter, M.E. Competitive Strategy: Techniques for Analyzing Industries and Competitors; The Free Press: New York, NY, USA, 1980. 
20. Navissi, F.; Sridharan, V.; Khedmati, M.; Lim, E.K.; Evdokimov, E. Business strategy, over- (under-) investment, and managerial compensation. J. Manag. Account. Res. 2017, 29, 63-86. [CrossRef]

21. Habib, A.; Hasan, M.M. Business strategy, overvalued equities, and stock price crash risk. Res. Int. Bus. Financ. 2017, 39, 389-405. [CrossRef]

22. Bentley-Goode, K.A.; Newton, N.J.; Thompson, A.M. Business strategy, internal control over financial reporting, and audit reporting quality. Audit. J. Pract. Theory 2017, 36, 49-69. [CrossRef]

23. Meng, Q.B.; Li, X.Y.; Cai, X.Y. Does company strategy affect company violations? Nankai Manag. Rev. 2018, 21, 116-129, 151.

24. Wang, Y.T.; Duan, M.R. Does corporate strategy affect management performance prediction behavior? Manag. Rev. 2019, 31, 200-213.

25. Lin, Y.E.; Li, Y.W.; Cheng, T.Y.; Lam, K. Corporate social responsibility and investment efficiency: Does business strategy matter? Int. Rev. Financ. Anal. 2021. [CrossRef]

26. Dziallas, M.; Blind, K. Innovation indicators throughout the innovation process: An extensive literature analysis. Technovation 2019, 80, 3-29. [CrossRef]

27. Nitin, P. Performance implications of strategic changes: An integrative framework. Bus. Horiz. 2015, 58, $295-304$.

28. Smith, W.K.; Tushman, M.L. Managing strategic contradictions: A top management model for managing innovation streams. Organ. Sci. 2005, 16, 522-536. [CrossRef]

29. Nadkarni, S.; Herrmann, P. CEO personality, strategic flexibility, and firm performance: The case of the indian business process outsourcing Industry. Aca. Manag. J. 2010, 53, 1050-1073. [CrossRef]

30. Yan, X.; Zhang, Y.; Pei, L.L. The impact of risk-taking level on green technology innovation: Evidence from energy-intensive listed companies in China. J. Clean. Prod. 2021. [CrossRef]

31. Akbar, S.; Kharabsheh, B.; Poletti-Hughes, J.; Shah, S.Z.A. Board structure and corporate risk taking in the UK financial sector. Int. Rev. Financ. Anal. 2017, 50, 101-110. [CrossRef]

32. Faccio, M.; Marchica, M.T.; Mura, R. Large shareholder diversification and corporate risk-taking. Rev. Financ. Stud. 2011, 24, 3601-3641. [CrossRef]

33. Faccio, M.; Marchica, M.T.; Mura, R. CEO gender, corporate risk-taking, and the efficiency of capital allocation. J. Corp. Financ. 2016, 39, 193-209. [CrossRef]

34. He, Y.; Yu, W.L.; Yang, M.Z. CEO's compound career experience, corporate risk-taking and corporate value. China Ind. Econ. 2019, 9, 155-173.

35. Shahzad, F.; Lu, J.; Fareed, Z. Does firm life cycle impact corporate risk-taking and performance? J. Multinatl. Financ. Manag. 2019, 51, 23-44. [CrossRef]

36. Chen, M.J.; Miller, D. Competitive attack, retaliation and performance: An expectancy-valence framework. Strateg. Manag. J. 1994, 15, 85-102. [CrossRef]

37. Torugsa, N.; Arundel, A. Rethinking the effect of risk aversion on the benefits of service innovations in public administration agencies. Res. Policy 2017, 46, 900-910. [CrossRef]

38. Imhof, M.J.; Seavey, S.E. Corporate risk-taking, firm value and high levels of managerial earnings forecasts. Adv. Account. 2014, 30, 328-337. [CrossRef]

39. Cohen, D.A.; Dey, A.; Lys, T.Z. Corporate governance reform and executive incentives: Implications for investments and risk taking. Contemp. Account. Res. 2013, 30, 1296-1332. [CrossRef]

40. Liu, Z.; Li, X.; Peng, X.; Lee, S. Green or non-green innovation? Different strategic preferences among subsidized enterprises with different ownership types. J. Clean. Prod. 2020. [CrossRef]

41. He, J.J.; Tian, X. The dark side of analyst coverage: The case of innovation. J. Financ. Econ. 2013, 109, 856-878. [CrossRef]

42. Fang, V.W.; Tian, X.; Tice, S. Does stock liquidity enhance or impede firm innovation? J. Financ. 2014, 69, 2085-2125. [CrossRef]

43. Wang, X.L.; Fan, G.; Hu, L.P. China's Marketization Index Report by Province, Publishing House; Social Science Literature Publishing House: Beijing, China, 2018.

44. Baron, R.M.; Kenny, D.A. The moderator-mediator variable distinction in social psychological research: Conceptual, strategic, and statistical considerations. J. Pers. Soc. Psychol. 1986, 51, 1173-1182. [CrossRef] [PubMed]

45. Wang, X.; Wang, X.B.; Bai, Z.Q. Research on the inverted U-shaped relationship between loan-to-deposit ratio and profitability of commercial banks: Introducing the intermediary effect model of non-performing loan rate. Sci. Res. Manag. 2020, 41, $230-238$.

46. Coles, J.L.; Li, Z.F. Managerial Attributes, Incentives, and Performance. Rev. Corp. Financ. Stud. 2020, 9, 256-301. [CrossRef] 